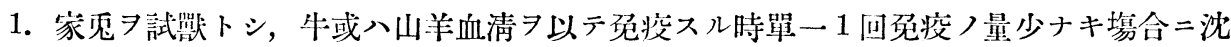

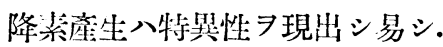

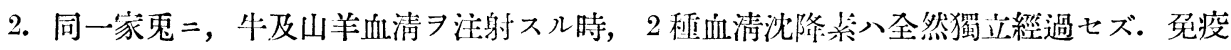

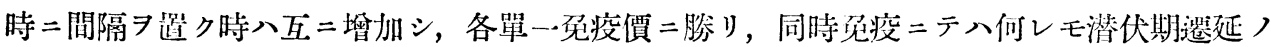
傾向アルガ如シ.

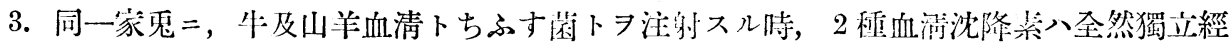

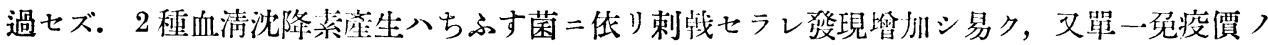
减退二際シ，ちふ寸菌免疫つ営メ急激ナル减退消失

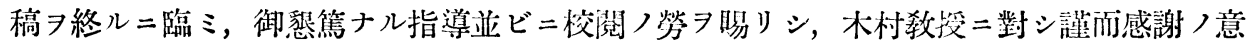
ᄏ表不.

\title{
參考 文献
}

1) L. Michaelis u. C. Oppencheimer, Archiv f. Anat.u. Physiol Abt. jg. $1902 . \quad$ 2) Michaelis, Deutsch. med. Wochenschr. Bd. 28, 1902. Deutsch med. Wochenschr. 1904. Nr. 34. 3) E. Benjanin u. O. Witzinger, Z. f. kinderh. Orig. Bd. 2, 1911. Bd. 3. 1912. 4) V. Dungern, Zeit. f. Imm. Bd. 21.5 5) H. Lewis and R. Weil, j. of. inf. Dis vol 17, 1915. 6) R. Doerr u. W. Berger, Z. f. Hyg. u. Inf. Bd. 93, 1921. Biochem. Z. Bd. 131, 1922.7 ) Dale, and. Haltley, Biochem. j. vol 10, 1916. 8) 丸鹤秀雄, 日本

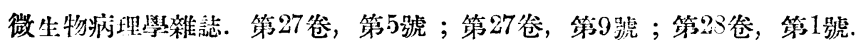
9) Unienhuth, Deutsch med. Wochenschr. 1900. Nr. 46, 1901. Nr. 6, 17, 30. 10) Nuttal, Proceedings

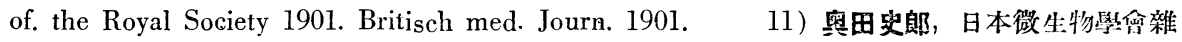

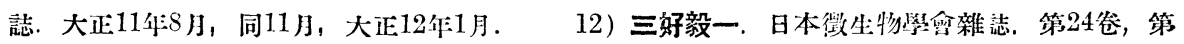

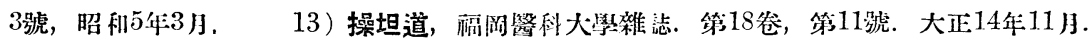

14）今井泰藏，日本微生物學俞雜誌。第9然，大正 8 年。 15）松下禎二, 悗疫學 16 )

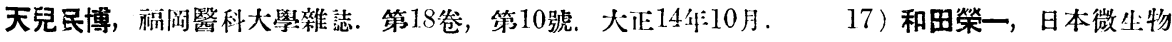

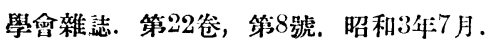

第28 管 1 號 丸野秀雄論文正誤表

\begin{tabular}{|c|c|c|c|}
\hline 頁 & 個 & 㒛 & is \\
\hline 51 & 第2行 & Simms. $\stackrel{\bullet}{\circ}$ EXP. & Simms. The. j. of EXP. \\
\hline 51 & 第5-6行 & Kandyba. f. Hyg. & Kandyba. Zschr. f. Hyg. \\
\hline 60 & 第11行 & Simms. Te. j. EXP. & Simms. The j. of. EXP. \\
\hline 60 & 第17行 & 大谷，友次 & 谷, 友次 \\
\hline
\end{tabular}

